\title{
Effect of Heat Treatments for Electroless Deposited Ni-B and Ni-W-B Coatings on 7075 Al Alloy
}

\author{
Rasid Ahmed Yildiz, Kenan Genel, and Turgut Gulmez
}

\begin{abstract}
Electroless Nickel — Boron (Ni-B) coatings has a wide range of usage area including aerocraft and automotive applications as well as $\mathbf{7 0 7 5}$ aluminum alloys. Electroless Ni-W-B deposits made a shift in wear resistance when compared to Ni-B coatings. In this study, an alkaline bath including sodium borohydride is used to reduce Nickel ions on the surface of 7075 aluminum alloy. Zincate treatment is the significant step before electroless deposition of Ni-B on aluminum alloys. During the deposition, $\mathrm{pH}$ and temperature values are set to appropriate range on the purpose of obtaining $20 \mu \mathrm{m}$ deposit. With the aim of high wear resistance of the coated system both Ni-B or Ni-W-B coated substrates are heat treated with different temperatures. Effect of heat treatment on the hardness values of the specimens; bare 7075, Ni-B coated and Ni-W-B were obtained. Considering hardness values appropriate time and temperatures were selected. After heat treatments SEM micrographs and EDS anaylsis of the coated systems were investigated.
\end{abstract}

Index Terms-7075 Aluminum alloy, electroless Ni-B, electroless Ni-W-B, heat treatment.

\section{INTRODUCTION}

Electroless nickel coatings are widely used to obtain superior corrosion and wear resistance. Owing to improved electro-chemical and mechanical properties, electroless nickel-boron (Ni-B) and electroless nickel-phosphorus (Ni-P) coatings have been used in many different applications; aerospace, automotive, chemical processing, oil and gas production, food, military and mining industry [1]. Aluminum has a great usage in aerospace industry because of its high strength to density ratio [2]. Electroless nickel coatings enhance aluminums constitutional characteristic by means of providing higher hardness, wear resistance and corrosion protection [3].

Deposition of nickel metal on a substrate in aqueous solution without electric source by means of catalytic reduction of nickel ions by adding reducing agent. While there have been a numerous studies on hypophosphite-reduced electroless plating, researches on boron, one of the most important amorphous elements, containing deposits has shifted. Sodium borohydride or dimethylamine borane (DMAB) is widely used as reducing agents to attain electroless Ni-B deposits [4], [5]. Electroless

Manuscript received October 1, 2015; revised January 6, 2016. This study was supported by Istanbul Technical University-BAP Department.

R. A. Yildiz and T. Gulmez are with the Istanbul Technical University, TR 34437, Istanbul, Turkey (e-mail: yildizras@itu.edu.tr, gulmezt@itu.edu.tr).

K. Genel is with the Sakarya University, TR 54187, Sakarya, Turkey (e-mail:kgenel@sakarya.edu.tr).
Ni-W-B deposition which provides higher wear resistance can be procured by adding sodium tungstate to the electroless Ni-B bath [6].

$7 \mathrm{xxx}$ series aluminum alloys have been used as structural materials in aerospace and automotive industry. Heat treatments have been developed to provide high strength and corrosion resistance concurrently [7]. Moreover, heat treatments applied to Ni-B and Ni-W-B deposits improves the wear resistance of coating [8].

Unfortunately, limited number of studies has been conducted on the effect of heat treatments of $\mathrm{Ni}-\mathrm{B}$ coatings on 7075 aluminum alloy. The present work aims to investigate the effect of mechanical properties of Ni-B and Ni-W-B coatings on 7075 aluminum alloy.

\section{EXPERIMENTAL PROCEDURE}

Commercial standard, chemical compostion can be seen in Table I, 7075 aluminum alloy has been used as a substrate in this study.

TABLE I: CHEMICAL COMPOSITION OF 7075 AL ALLOY

\begin{tabular}{cc}
\hline Element & \% Weight Percentage \\
\hline $\mathbf{Z n}$ & 5,8 \\
\hline $\mathbf{M g}$ & 2,4 \\
\hline $\mathbf{C u}$ & 1,5 \\
\hline $\mathbf{F e}$ & 0,26 \\
\hline $\mathbf{C r}$ & 0,19 \\
\hline $\mathbf{S i}$ & 0,08 \\
\hline $\mathbf{M n}$ & 0,03 \\
\hline $\mathbf{T i}$ & 0,08
\end{tabular}

Vickers hardness measurements were carried out on both the coating and substrate by applying loads between $50-200$ $\mathrm{g}$ with SHIMADZU HMV2. To achieve optimum electroless bath temperature and hardness measurements aluminum samples $20 \times 50 \times 40 \mathrm{~mm}^{3}$ were used.

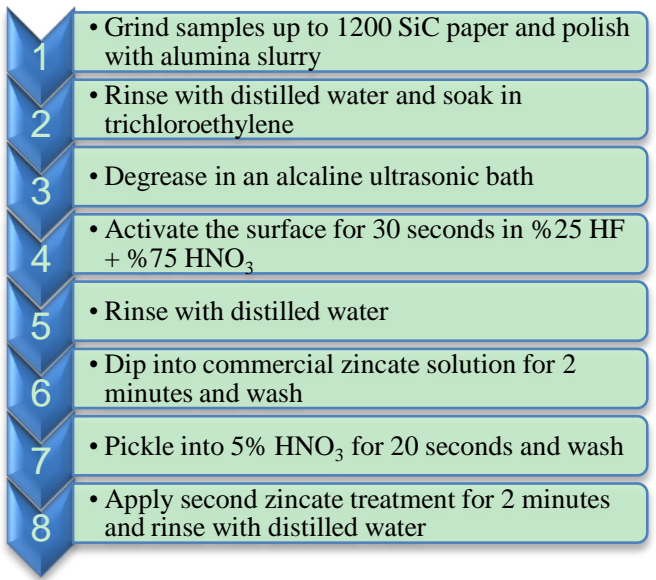

Fig. 1. Steps for zincate treatment procedure applied on aluminum [10] 
An alkaline bath composition in Table II containing sodium borohydride as a reducing agent for nickel ions were used to deposit Ni-B and Ni-W-B on aluminum substrates.

Zincate treatment is a crucial step for aluminum alloys before immersing the samples into electroless bath [9]. Zincate treatment discovered by HINO et al. was implemented respectively in Fig. 1 [10].

Sodium borohydride is one of the most powerful reducing agent in order to attain electroless nickel deposition. $\mathrm{pH}$ of the electroless nickel bath is demanded between 12 to 14 and the reduction reaction is expected as following [11];

$$
2 \mathrm{Ni}^{2+}+2 \mathrm{BH}_{4}^{-}+4 \mathrm{H}_{2} \mathrm{O} \rightarrow 2 \mathrm{Ni}^{0}+\mathrm{B}+\mathrm{B}(\mathrm{OH})_{4}^{-}+3 \mathrm{H}^{+}+\frac{9}{2} \mathrm{H}_{2}
$$

Furthermore, as a complexing agent ethylenediamine were used to prevent precipitation of nickel hydroxide. As a stabilizer lead tungstate were utilized to control the reactions on the substrate [12].

Experimental setup of electroless $\mathrm{Ni}-\mathrm{B}$ and $\mathrm{Ni}-\mathrm{W}-\mathrm{B}$ depositions as depicted in Fig. 2 with magnetic stirrer heater operated and temperature of the bath measured with thermometer.

TABLE II: ElECTROLESS Ni-B Plating BATH CHEMICAL COMPOSITION

\begin{tabular}{cc}
\hline Chemical Compound & Percentage \\
\hline Nickel Chloride & $24 \mathrm{~g} / \mathrm{L}$ \\
\hline Sodium Borohyride & $2 \mathrm{~g} / \mathrm{L}$ \\
\hline Ethylenediamine & $72 \mathrm{ml} / \mathrm{L}$ \\
\hline Potassium Hydroxide & $29 \mathrm{~g} / \mathrm{L}$ \\
\hline Lead Tungstate & $0,01 \mathrm{~g} / \mathrm{L}$ \\
\hline Ethylenediamine Tetra Acetate & $0,65 \mathrm{~g} / \mathrm{L}$ \\
\hline
\end{tabular}

Measured $\mathrm{pH}$ values ranges $13.5 \pm 0.2$ and temperature was set to $92 \pm 1^{\circ} \mathrm{C}$ controlled by a temperature controller. $\mathrm{pH}$ values were controlled by means of $\mathrm{NaOH}$ addition.

In order to attain $20 \mu \mathrm{m}$ deposition layer aluminum substrates were immersed 2 hours in the bath.

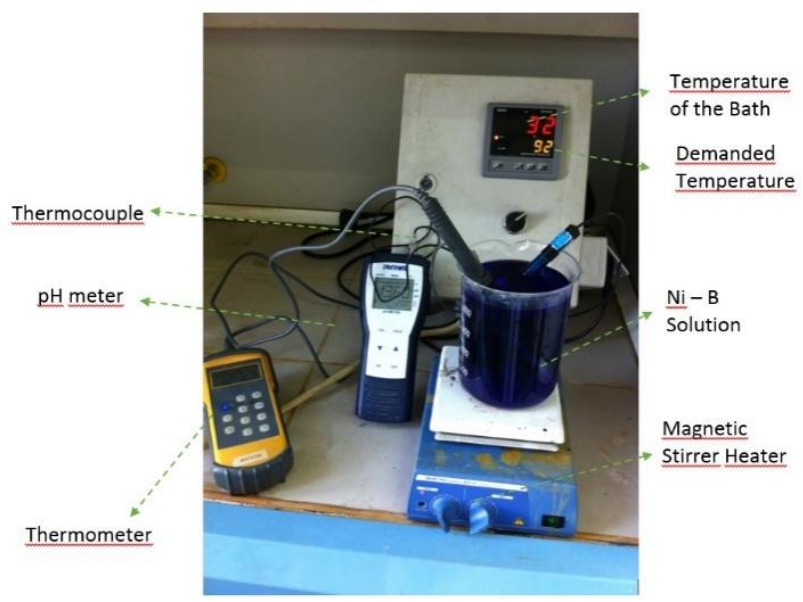

Fig. 2. Experimental setup for electroless plating solutions.

\section{EXPERIMENTAL RESULTS}

7075 aluminum alloy substrate had a microhardness value of $60 \pm 1 \mathrm{HV}_{0.1}$. High temperatures provide quick response in hardness however 7075 aluminum alloys hardness increase in time. Therefore, different heat treatment conditions were executed at temperatures $125^{\circ} \mathrm{C}, 150^{\circ} \mathrm{C}$ and $175^{\circ} \mathrm{C}$. After heat treatments exerted on uncoated substrate, electroless $\mathrm{Ni}-\mathrm{B}$ coated and electroless Ni-W-B specimens, microhardness measurements performed. As it can be seen in Fig. 3, maximum hardness value is obtained by 24 hours heat treatment at $125^{\circ} \mathrm{C}$. Precipitation hardened $7075 \mathrm{Al}$ alloys strength increase with regard to hardness [13].

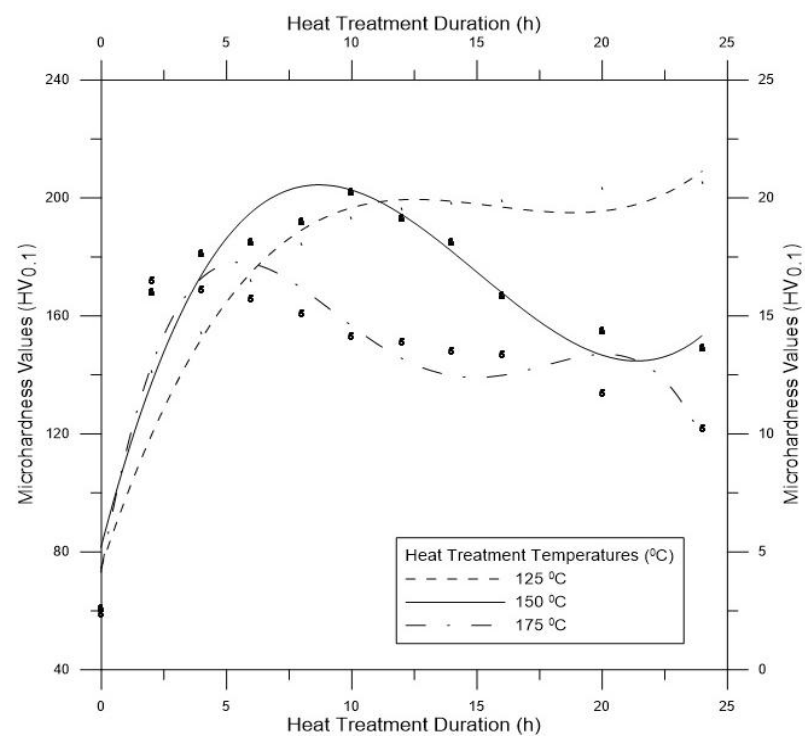

Fig. 3. Effect of heat treatments on $7075 \mathrm{Al}$ Alloys hardness.

In Fig. 4, maximum hardness value of electroless $\mathrm{Ni}-\mathrm{B}$ deposit on $7075 \mathrm{Al}$ alloy is achieved at $150^{\circ} \mathrm{C}$ and $175^{\circ} \mathrm{C}$ after $10-12$ hours of heat treatment. Electroless Ni-B coatings are mainly used to provide a shift on wear resistance of materials. Electroless Ni-B and Ni-W-B coatings are in amorphous in the as-plated condition. Heat treatment, the increase in the hardness of the coating enhances the plastic resistance of the deposit. Hence the friction coefficients and wear rates for heat-treated electroless $\mathrm{Ni}-\mathrm{B}$ coatings are less when compared to as-plated specimens [14], [15]. Besides, heat treated Ni-B coatings exhibit spectacular adhesion on substrate [12].

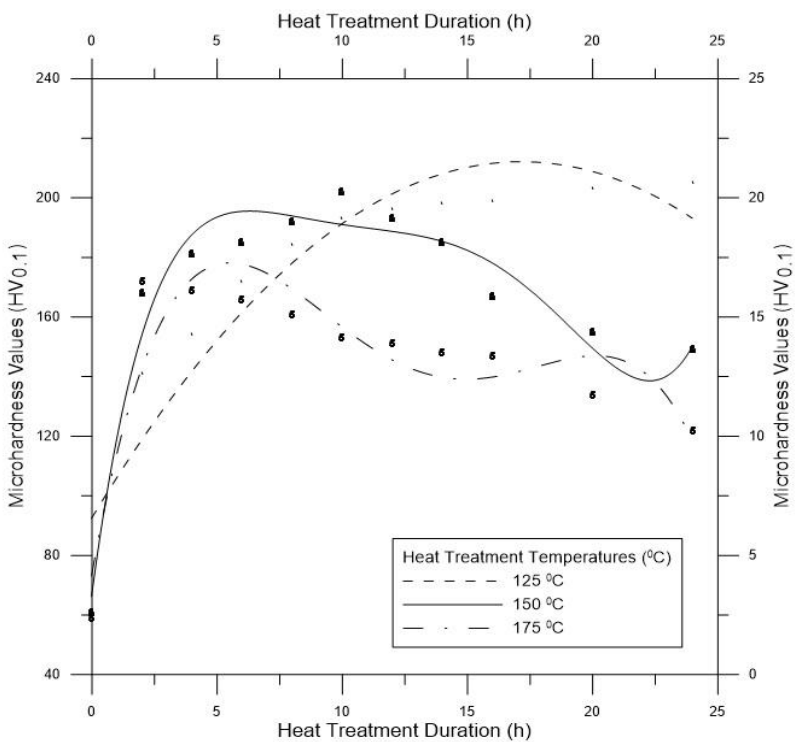

Fig. 4. Effect of heat treatments of Ni-B coated $7075 \mathrm{Al}$ alloys hardness.

In Fig. 5, determined hardness values are shifted due to addition of 'Tungsten' but similar to Ni-B coatings that 
maximum hardness achieved at $150^{\circ} \mathrm{C}$ and $175^{\circ} \mathrm{C}$ at $10-12$ hours of heat treatment. Exhibited in the previous study, Tungsten diffuses through the grain boundaries and form tungsten-oxide film on the surface which cause an increase not only on hardness and wear resistance but also corrosion resistance [8].

According to the Figs. 3, 4 and 5, increasing wear resistance could be possible by $10-11$ hours heat treatment held at $150^{\circ} \mathrm{C}$ of the specimens. $7075 \mathrm{Al}$ alloy specimens electroless coated with $\mathrm{Ni}-\mathrm{B}$ and $\mathrm{Ni}-\mathrm{W}-\mathrm{B}$ were seized at the drying oven at $150^{\circ} \mathrm{C}$ for 10 hours.

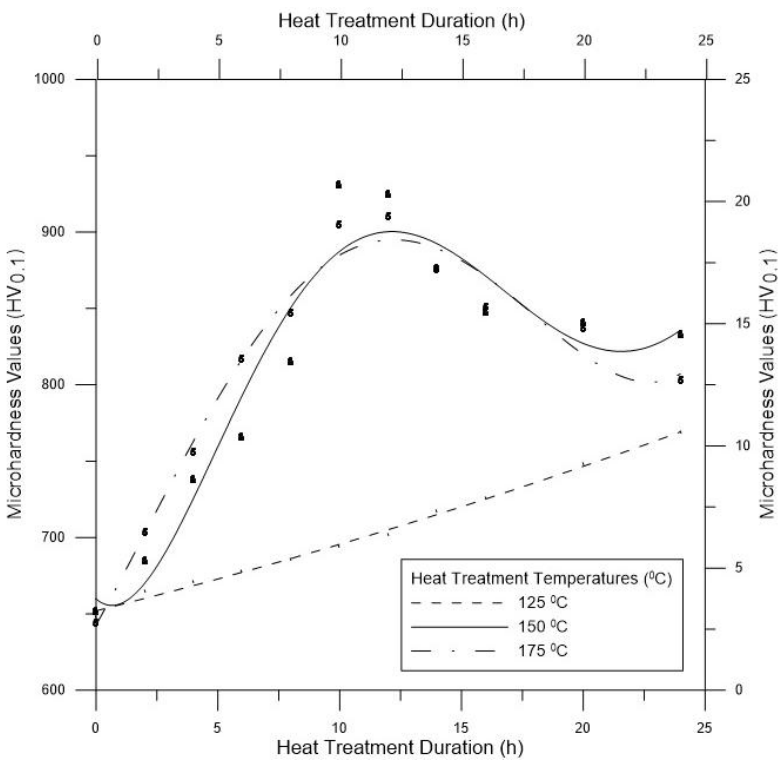

Fig. 5. Effect of heat treatments of Ni-W-B coated $7075 \mathrm{Al}$ alloys hardness.

After implementing the heat treatments to define the chemical composition of coatings EDS analysis were executed. However, determining of 'Boron' content is not possible. Electroless Ni-B coated specimens result pointed that coating consists of $\mathrm{Ni}, \mathrm{Pb}$ and oxide compounds of them as depicted in Fig. 6. The reason for determining leads in the EDS analysis explained by using Lead Tungstate $\left(\mathrm{PbWO}_{4}\right)$ as a stabilizer. Introducing Lead $(\mathrm{Pb})$ onto coating provides uniformity and shifted adhesion strength [12], [16], [17].

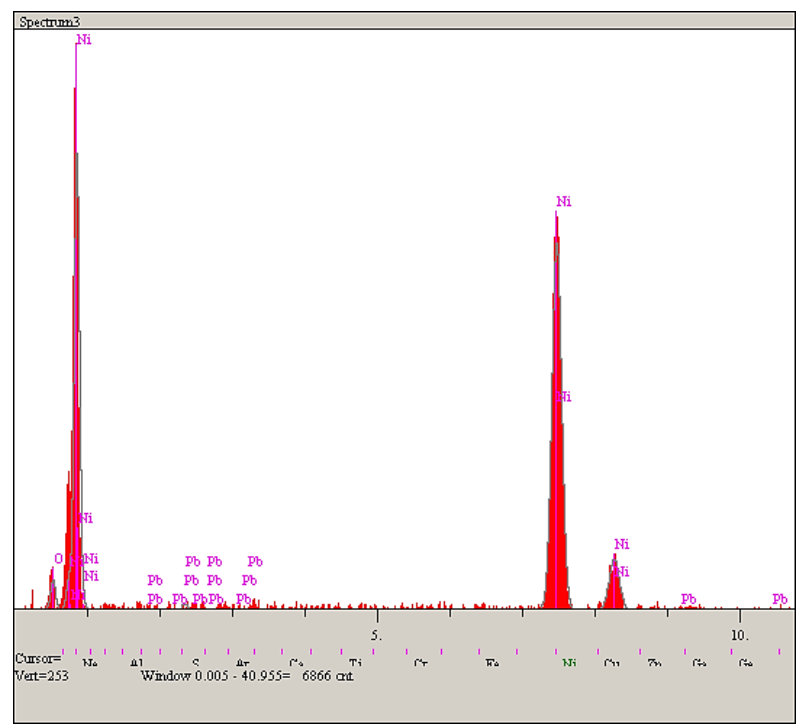

Fig. 6. EDS analysis of Ni-B coated $7075 \mathrm{Al}$ alloy.

Moreover, the 'cauliflower' like microstructure which can be seen in Fig. 7 of the Ni-B were analyzed by means of EDS.

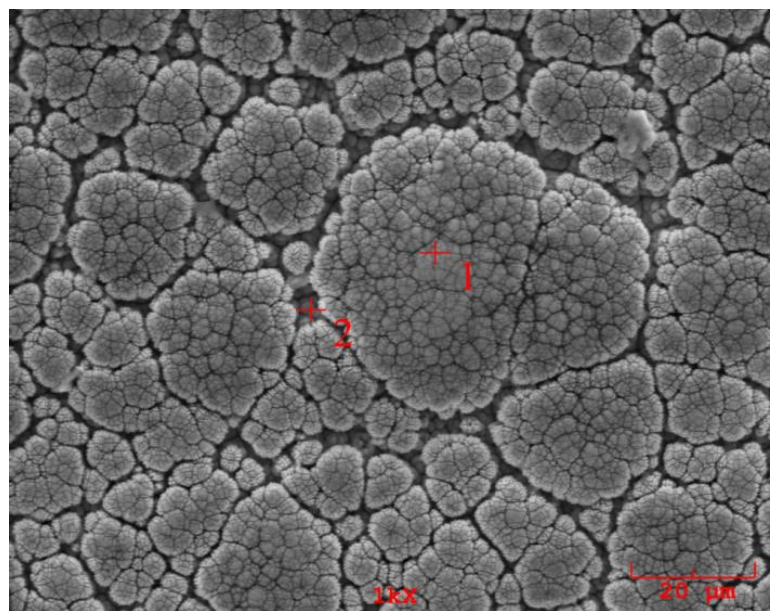

Fig. 7. SEM micrograph of Ni-B coating on $7075 \mathrm{Al}$ alloy.

Nevertheless there have not been much difference for compounds between the point on "cauliflower" and "blanks" as given in Table III.

TABLE III: EDS ANALYSIS FOR ELECTROLESS NI-B DEPOSITED 7075 AL

\begin{tabular}{|c|c|c|c|c|c|c|}
\hline Element & \multicolumn{2}{|c|}{ Intensity (c/s) } & \multicolumn{2}{c|}{ Error (20) } & \multicolumn{2}{c|}{$\begin{array}{c}\text { Result } \\
\text { (\% Weight) }\end{array}$} \\
\hline & $\mathbf{1}$ & $\mathbf{2}$ & $\mathbf{1}$ & $\mathbf{2}$ & $\mathbf{1}$ & $\mathbf{2}$ \\
\hline $\mathbf{N i}$ & 286.1 & 277.7 & 10.6 & 9.43 & 93.18 & 92.8 \\
\hline $\mathbf{O}$ & 10.5 & 9.01 & 2.04 & 1.89 & 4.02 & 4.28 \\
\hline $\mathbf{P b}$ & 3.88 & 3.74 & 0.59 & 0.67 & 1.78 & 1.81 \\
\hline
\end{tabular}

After heat treated at $150^{\circ} \mathrm{C}$ for 10 hours electroless Ni-W-B deposited 7075 Aluminum alloys EDS analysis have shown that coating contains Tungsten depicted in Fig. 8.

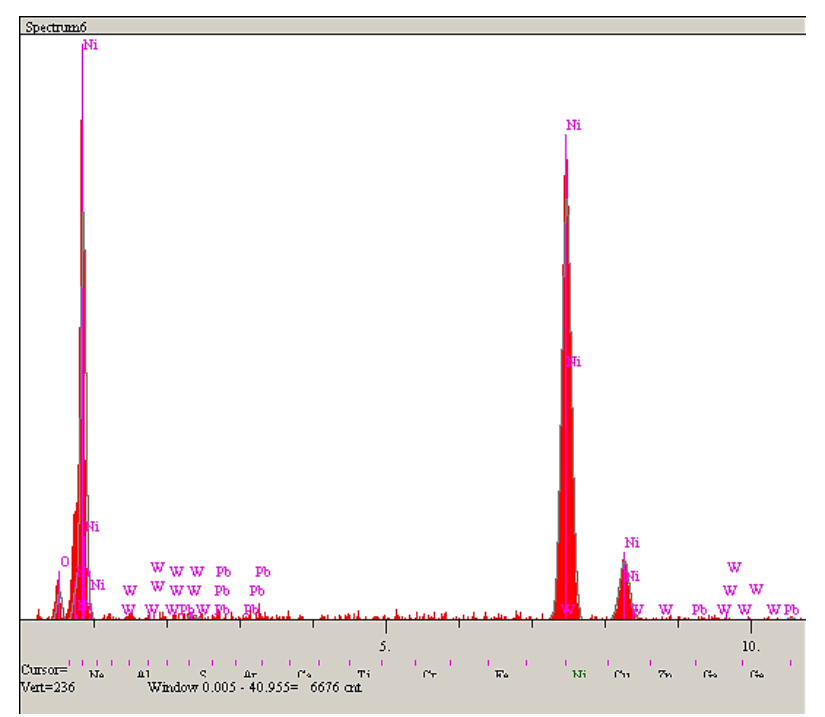

Fig. 8. EDS analysis of Ni-W-B coated $7075 \mathrm{Al}$ alloy.

In addition, SEM micrographs for $\mathrm{Ni}-\mathrm{W}-\mathrm{B}$ coatings have resemblance to Ni-B coatings denoted in Fig. 9. Provided $\mathrm{Ni}-\mathrm{W}-\mathrm{B}$ coatings hardness values are above than $\mathrm{Ni}-\mathrm{B}$ coatings due to formation of hard particles.

TABLE IV: EDS ANALYSIS FOR ELECTROLESS NI-W-B DEPOSITION ON 7075 ALUMINUM ALLOY

\begin{tabular}{|l|l|l|l|l|l|l|}
\hline Element & \multicolumn{3}{|l|}{ Intensity (c/s) } & \multicolumn{2}{l|}{ Error (20) } & \multicolumn{2}{l|}{ Result (\% Weight) } \\
\hline & $\mathbf{1}$ & $\mathbf{2}$ & $\mathbf{1}$ & $\mathbf{2}$ & $\mathbf{1}$ & $\mathbf{2}$ \\
\hline $\mathbf{N i}$ & 284.3 & 286.7 & 10.6 & 10.7 & 88.8 & 90.0 \\
\hline $\mathbf{W}$ & 1.49 & 1.24 & 0.77 & 0.61 & 4.52 & 3.71 \\
\hline $\mathbf{O}$ & 13.0 & 11.5 & 2.28 & 1.57 & 4.21 & 3.69 \\
\hline $\mathbf{P b}$ & 1.11 & 1.82 & 0.66 & 0.85 & 1.21 & 1.74 \\
\hline
\end{tabular}


Two points selected as well as on the Ni-W-B coating. Serious difference has not been detected in the EDS analysis results represented in Table IV.

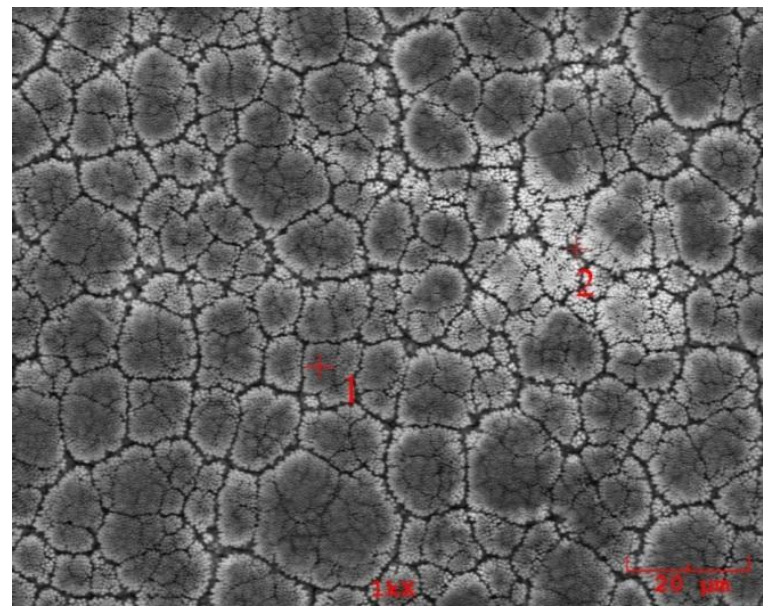

Fig. 9. SEM micrograph of Ni-W-B deposition on $7075 \mathrm{Al}$ alloy.

\section{CONCLUSION}

$\mathrm{Ni}-\mathrm{B}$ and $\mathrm{Ni}-\mathrm{W}-\mathrm{B}$ coatings were applied on 7075 aluminum alloy by electroless deposition technique using solutions including Lead Tungstate as a stabilizer and Sodium Tungstate as Tungstate former. Zincate treatment is a substantial process of Aluminum alloys before the electroless deposition of Ni-B and Ni-W-B coatings. In order to increase wear resistance and fatigue life of coated specimens, heat treatments should be executed. Three different temperatures $\left(125,150\right.$ and $\left.175^{\circ} \mathrm{C}\right)$ were picked considering aging time of 7075 Aluminum alloy. The graphs (Figs. 3, 4 and 5) gathered after microhardness tests upon implemented heat treatments. Maximum hardness values for both substrate and coatings are determined when coated system is heat treated at $150^{\circ} \mathrm{C}$ for 10 hours. SEM micrographs have shown that Ni-B coated specimen has a 'cauliflower' like microstructure after heat treatments which enable the coated system to perform lower wear rates. On the other hand, Ni-W-B coated systems which ensure higher hardness. SEM micrographs are similar to $\mathrm{Ni}-\mathrm{B}$. EDS analysis have proved that coating contains "W" as ternary coating.

Many studies have proven that $\mathrm{Ni}-\mathrm{B}$ and $\mathrm{Ni}-\mathrm{W}-\mathrm{B}$ coatings are amorphous at as-plated condition. By virtue of heat treatments applied on Ni-B and Ni-W-B coated 7075 aluminum alloy, microhardness values are increased which procures lower wear rates and give rise to be at crystallographic condition as referred in related works.

\section{REFERENCES}

[1] W. Riedel, Electroless Nickel Plating, ASM International, 1991.

[2] C. Villalobos-Gutierrez, I. Irausquin, J. L. Barbera-Sosa et al., "Fatigue Behaviour of a 7075-T6 aluminum alloy coated with an electroless Ni-P deposit," International Journal of Fatigue, no. 28, pp. 1854-1866, 2006.

[3] Z. Y. Shi, D. Q. Wang, and Z. M. Ding, "Surface strenghening pure copper by Ni-B coating," Applied Surface Science, no. 221, pp. 62-68, 2004 .

[4] Z. Abdel Hamid, H. B. Hassan, and A. M. Attyia, "Influence of deposition temperature and heat treatment on the performance of electroless Ni-B films," Surface \& Coatings Technology, no. 205, pp. 2348-2354, 2010.

[5] D. W. Baudrand, Electroless Nickel Plating, 5th ed. ASM, 1994
[6] A. B. Drovosekov, "Chemically deposited Ni-W-B coatings: Composition, structure and properties," Protection of Metals, vol. 41, no. 1 , pp. 61-68, 2005 .

[7] J. F. Li, "Mechanical properties, corrosion behaviours and microstructure of 7075 aluminum alloy with various aging treatments," Transactions of Nonferrous Metals Society of China, no. 18, pp. 755-762, 2008.

[8] R. A. Yildiz, A. Goksenli, B. Yuksel, F. Muhaffel, and A. Aydeniz, "Effect of annealing temperature on the corrosion resistance of electroless produced Ni-B-W coatings," Advanced Materials Research, vol. 651, pp. 263-268, 2013.

[9] K. Azumi, M. Seo, and L. Nanis, "Changes in potential and weight of aluminum alloy during double zincate process," Journal of Surface Finishing Society of Japan, vol. 47, pp. 529-535, 1996

[10] M. Hino, K. Murakami, Y. Mitooka, K. Muraoka, and T. Kanadani, "Effects of zincate treatment on adhesion of electroless Ni-P coating onto various aluminum alloys," Transactions of Nonferrous Metals Society of China, vol. 19, pp. 814-818, 2009.

[11] C. T. Dervos, J. Novakovic, and P. Vassiliou, "Vacuum heat treatmen of electroless Ni-B coatings," Materials Letters, no. 58, pp. 619-623, 2004.

[12] F. Delaunois and P. Lienard, "Heat treatments for electroless Nickel-Boron plating on aluminum alloys," Surface and Coatings Technology, no. 160, pp. 239-248, 2002.

[13] Metals Handbook, ASM International, 1992, vol. 2.

[14] K. Krishnaveni, T. S. N. Sankara Narayanan, and S. K. Seshadri, "Electroless Ni-B coatings: Preparation and evaluation of hardness and wear resistance," Surface Coatings and Technology, no. 190, pp 115-121, 2005.

[15] A. R. Di Giampaolo, J. G. Ordonez, J. M. Gugliemacci, and J. Lira, "Electroless nickel-boron coatings on metal carbides," Surface Coatings and Technology, no. 89, pp. 127-131, 1997.

[16] F. Kanta, M. Poelman, V. Vitry, and F. Delaunois, "Nickel-boron electrochemical properties investigations," Alloys and Compounds, no. 505, pp. 151-156, 2010.

[17] B. Kaya, T. Gulmez, and M. Demirkol, "Study on the electroless Ni-B nano-composite coatings," Transactions on Engineering Technologies, vol. 2, pp. 62-73, 2009.

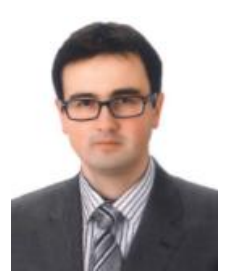

Rasid A. Yildiz is a research assistant at the Mechanical Engineering Department of Istanbul Technical University, Turkey. He was born in Rize in 1987. He received his BSc. on mechanical engineering in 2009. He earned his MSc. from Istanbul Technica University on materials and manufacture program in 2012. He pursues his PhD study at Istanbul Technical University on mechanical engineering in Turkey.

$\mathrm{He}$ worked as a research assistant at Sakarya University from 2009 to 2012 . After three years in Sakarya, he decided to pursue his career in Istanbul and he has been working as a research assistant in Istanbul Technical University, Turkey from 2012. He had completed his military service in 2015. He has three papers on electroless Ni-B coatings published in indexed journals. He recently, carries out studies on sheet metal forming of aluminum alloys.

Mr. Yildiz has been granted scholarships from Usak Education and Culture Foundation and Izmir Metropolitan Municipality.

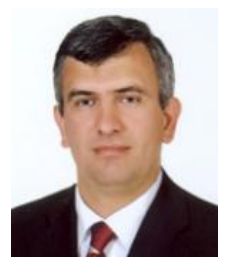

Kenan Genel is the head of the Department of Mechanical Engineering in Sakarya University, Turkey. He is also working as Professor in Sakarya University Mechanical Engineering. He earned his $\mathrm{BSc}, \mathrm{MSc}$ and $\mathrm{PhD}$ degrees from Istanbul Technical University on mechanical engineering.

$\mathrm{He}$ has been working as Professor in Sakarya University, Mechanical Engineering Department. He has 26 papers published in SCI journals and several conference papers. He is recently working on composite materials.

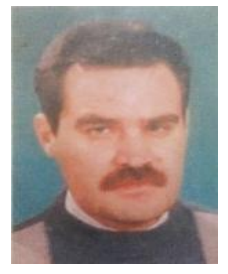

Turgut Gulmez is working as Associate Professor in Istanbul Technical University. He received his BSc, MSc and PhD degrees from Istanbul Technical University on mechanical engineering.

$\mathrm{He}$ is currently working as an Associate Professor in Mechanical Engineering Department of Istanbu Technical University. He has 22 journal papers and several conference papers including materials science and manufacturing. 